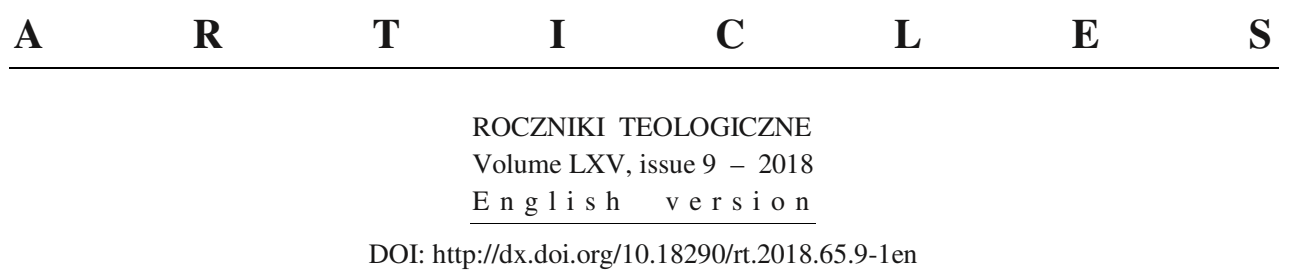

REV. JACENTY MASTEJ

\title{
FROM THE PAGES OF THE HISTORY OF KUL'S INSTITUTE OF FUNDAMENTAL THEOLOGY: ITS EMPLOYEES AND STRUCTURE. INTRODUCTION
}

\begin{abstract}
The activity of the Department of Fundamental Theology (from 1918), then the Section of Fundamental Theology, and from 1999 the Institute of Fundamental Theology (IFT) shares the $100^{\text {th }}$ anniversary of the existence of John Paul II Catholic University of Lublin. The aim of the article is to present the evolution of the IFT structure and the people who contributed to its development.
\end{abstract}

Keywords: John Paul II Catholic University of Lublin; Section of Fundamental Theology; Institute of Fundamental Theology; Department of Fundamental Christology and Ecclesiology; Department of History and Ethnology of Religion; Department of Religious Studies and Missiology.

The $100^{\text {th }}$ anniversary of the founding of the John Paul II Catholic University of Lublin is an excellent opportunity to bring the presence of the Institute of Fundamental Theology closer to the University's life. The editors of the Roczniki Teologicznych [Theological Annals] number 9 in 2018 give us a multifaceted presentation of the significant academic research achievements of the Institute of Fundamental Theology, which is why most of the articles contained in this notebook were prepared by the Institute's employees. Research and didactic work, first in the framework of the Fundamental Theology Section and then the Institute of Fundamental Theology, resulted in the creation of the Lublin school of fundamental theology. A substantive

Rev. Dr. Hab. Jacenty Mastej, KUL professor, is the head of the Department of Fundamental Christology and Ecclesiology; Institute of Fundamental Theology, John Paul II Catholic University of Lublin, Al. Racławickie 14, 20-950 Lublin; lecturer in fundamental theology at the Priestly Formation Seminary in Rzeszów; address for correspondence-e-mail: jmastej@kul.pl 
and detailed discussion of the achievements of this school is included in the following part of this issue and will be preceded by a presentation of the changes that took place in the IFT's structure along with a presentation of the people who contributed to its development.

The Department of Fundamental Theology and the Department of History of Religion, which form the core of the Institute of Fundamental Theology, were founded at the first meeting of the Catholic University Senate in autumn of 1918. The Chair of Fundamental Theology was entrusted to Rev. Piotr Kremer, a former professor at the Academy of Catholic Theology in St. Petersburg, a close associate of Rev. Idzi Radziszewski from the times of the Spiritual Academy in St. Petersburg (Moskal 2009, 15-20, Łukaszyk 1968, 12-13). Rev. Prof. P. Kremer became the first dean of the Faculty of Theology at the Catholic University of Lublin. Lectures on the history of religion in the years 1918-1920 were led Rev. Józef Archutowski, professor of Sacred Scriptures (Łukaszyk 1968, 13). In November 1920, the Council of the KUL Faculty of Theology created four sections: biblical studies, fundamental theology, dogmatic theology and moral theology (Misiurek 1999, 11). During this time, the lectures were conducted by: Rev. Prof. P. Kremer, Rev. Dr. Roman Konecki (1923/24) and Rev. Bishop Dr. Czesław Sokołowski (1924/25) (Kaucha 2014, 53). In October 1929, the Faculty of Theology reorganized. Rev. P. Kremer was still the Chair and headed the Fundamental Theology Section, and lectures on the history of religion in the years 19301939 were given by Rev. Dr. Józef Kruszyński from the Biblical Theology Section (Łukaszyk 1968, 14).

In January 1945, Rev. Prof. Adolf Tymczak was entrusted with leading the Section and the Department of Fundamental Theology, a former associate professor at the Jan Kazimierz University in Lviv and a professor at the Seminary in Przemyśl. In the academic year 1945/46, this function was taken over by Rev. Dr. Edward Bulanda, who in 1945-1949 taught comparative history of religion (Łukaszyk 1968, 14-15). On May 31, 1946, the Council of the Faculty of Theology made Rev. Dr. Bolesław Radomski head of the chair of the Department of Fundamental Theology. At that time, he was a professor of the Seminary in Lodz, assistant professor at the University of Warsaw. The Council him the post of associate professor, entrusting him with the management of the Fundamental Theology Section (Story 2002/ 2003, 327-328, Łukaszyk 1968, 15-17, Marczewski 2009, 79-80). 
After the tragic death of Rev. B. Radomski in 1956, his place was taken by Rev. Dr. Edward Kopeć, former lecturer at the Higher Theological Seminary in Wrocław (Rusecki 1985, 7-22, Rusecki 2009, 167-176). In the years 19561959, the Section of Fundamental Theology was headed by Rev. Dr Bogusław Waczyński (Łukaszyk 1968, 17-18). In 1957, lectures were delivered by Rev. Dr. Czesław S. Bartnik for the Section (Łukaszyk 1968, 24-26).

On February 18, 1958, the Council of the Faculty of Theology reactivated the Department of the History of Religion, electing Rev. Dr. Teofil Chodzidła SVD as substitute director (Łukaszyk 1968, 29-22). In turn, on June 23, 1958, the Second Chair of Fundamental Theology and Ecclesiology was established, entrusting lectures in this discipline to Rev. Dr. Stanisław Nagy, SCJ (Seweryniak 1996, 8-10). Thus, since 1958, the Fundamental Theology Section consists of three departments: I. The Department of Fundamental Theology and Christology, whose head in the years 1961-1985 was Rev. Prof. E. Kopeć, while in the years 1986-2010 the chair was headed by Rev. Prof. Marian Rusecki (employed on October 1, 1974) (Ledwoń 2007, 3-7, Kaucha 2013, 5-12); II. The Chair of Fundamental Theology and Ecclesiology, lead by Rev. Prof. S. Nagy SCJ in the years 1964-1991 (Eukaszyk 1968, 22-24); III. The Department of History and Ethnology of Religion, headed by Fr. Prof. T. Chodzidło SVD in the years 1961-1976, and from November 1985 to September 30, 2012, by Fr. Prof. Henryk Zimoń SVD (employed on October 1, 1973) (Misiurek 1999, 15-37, Kupisiński 2010, 26-30).

In 1999, the Fundamental Theology Section was renamed the Institute of Fundamental Theology, composed of 3 departments: Fundamental Christology, Fundamental Ecclesiology, and the History and Ethnology of Religion (Misiurek 2008, 58-60).

The IFT directors were: until August 31, 2008 Rev. M. Rusecki; September 1, 2008-March 31, 2011 Rev. H. Zimoń; April 1, 2011-August 31, 2016 Rev. K. Kaucha, and since September 1, 2016 the IFT director is Rev. J. Mastej.

In 2003, Rev. Dr. Stanisław Grodź SVD was employed at the Department of History and Ethnology of Religion (he worked until 2016). On October 1, 2005, the Rev. Dr. Andrzej Pietrzak SVD began work in the Department of Fundamental Ecclesiology. On October 1, 2007, the fourth chair in the IFT was created, the Department of Theology of Religion, and Fr. I.S. Ledwon was appointed its head. On October 1, 2009, the following were recruited: Rev. Dr. Paweł Borto at the Department of Fundamental Ecclesiology and 
Fr. Dr. Adam Wąs SVD (who worked until 2016) in the Department of Theology of Religion. On February 15, 2009, the head of the Department of Fundamental Ecclesiology became Rev. K. Kaucha. On October 1, 2010, the fifth chair of the IFT opened, the Chair of Missiology, which was entrusted to Rev. M. Rusecki (he managed it until his death on December 15, 2012). Upon entrusting the Chair of Missiology to Rev. M. Rusecki, Rev. J. Mastej became the head of the Department of Fundamental Christology. In the years 2011-2013, Dr. Józef Nowak worked in the Department of History and Ethnology of Religion, and in the academic year 2011/12 lectures in the field of religious studies were conducted by Dr. Wiesław Bator ( $1 / 2$ part-time). In 2012-2015, Rev. Dr. Krystian Kałuża worked in the Department of Theology of Religion.

On March 1, 2013, the Department of History and Ethnology of Religion was transformed into the Department of Religious Studies. On October 1, 2013, the Department of Fundamental Ecclesiology and the Chair of Missiology were merged. The new chair was given the name: the Department of Fundamental Ecclesiology and Missiology, and its head was Rev. K. Kaucha. Another reorganization of the IFT's chairs took place on June 11, 2014. As a result of the transformations, two departments remained: the Department of Fundamental Christology and Ecclesiology (Rev. J. Mastej became the head) and the Department of Religious Studies and Missiology, headed by Rev. Z. Kupisiński. At that time, the Department of Theology of Religion was directed by Fr. I.S. Ledwoń.

After the reorganization of the chairs, which took place on October 1, 2016, the IFT consists of two departments: the Chair of Fundamental Christology and Ecclesiology employing KUL Prof. Rev. J. Mastej, (director), KUL Prof. Rev. K. Kaucha, Rev. Dr. P. Borto, Assistant Professor and Rev. Dr. Paweł Tambor, assistant (employed on October 1, 2016) and the Department of Religiology and Missiology employing KUL Prof. Rev. Z. Kupisiński (director), KUL Prof. Fr. I.S. Ledwoń and KUL Prof. Rev. A. Pietrzak.

\section{BIBLIOGRAPHY}

BAnASZAK, Marian. "Ksiądz Romuald Łukaszyk (1930-1981)” [Fr. Romuald Łukaszyk (19301981)]. Roczniki Teologiczno-Kanoniczne 3, no 2 (1984): 5-7.

KAUCHA, Krzysztof. "Doctor Credibilitatis. Śp. Rev. prof. dr hab. dr hc Marian Jan Rusecki (22 III 1942-15 XII 2012)" [Doctor Credibilitatis. The Late Rev. Prof. Marian Jan Rusecki 
(March 22, 1942-December 15, 2012)]. Roczniki Teologii Fundamentalnej i Religiologii 5(60) (2013): 5-12.

KAUCHA, Krzysztof. "Wiarygodność i wiara w ujęciu lubelskiej szkoły teologii fundamentalnej." In Wiara-wiarygodność [Credibility and Faith in the Lublin School of Fundamental Theology. In: Faith-Credibility], edited by Damian Wąsek, 49-85. Kraków: Wydawnictwo Naukowe UPJPII, 2014.

KUPISIŃSKI, Zdzisław. “Życiorys i działalność naukowa księdza profesora Henryka Zimonia SVD.” In Pluralizm kulturowy i religijny wspótczesnego świata. Księga pamiątkowa dedykowana księdzu profesorowi Henrykowi Zimoniowi SVD w 70. rocznice urodzin [Biography and Academic Activity of Father Professor Henryk Zimon SVD. In: Cultural and Religious Pluralism in the Modern World. A Commemorative Book Dedicated to Fr. Prof. Henryk Zimon SVD on the his $70^{\text {th }}$ Birthday.], edited by Zdzisław Kupisiński, Stanisław Grodź, 22-45. Lublin: Wydawnictwo KUL, 2010.

Ledwoń, Ireneusz. “Curriculum vitae.” In Scio Cui credidi. Księga pamiątkowa ku czci Księdza Profesora Mariana Ruseckiego w 65. rocznice urodzin [Curriculum vitae. In: Scio Cui credidi. A Book in Honor of Father Professor Marian Rusecki on his $65^{\text {th }}$ Birthday], edited by Ireneusz Ledwoń, Krzysztof Kaucha, Zbigniew Krzyszowski, Jacenty Mastej, Andrzej Pietrzak, 3-7. Lublin: Wydawnictwo KUL, 2007.

ŁUKASZYK, Romuald. "Pięćdziesięciolecie teologii fundamentalnej na KUL (1919-1968)" [Fifty Years of Fundamental Theology at KUL (1919-1968)]. Roczniki Teologiczno-Kanoniczne 15(2) (1968): 5-53.

MARCZewski, Jarosław. “Bolesław Józef Radomski.” In Dziekani Wydziału Teologii Katolickiego Uniwersytetu Lubelskiego Jana Pawła II (1919-2009) [Bolesław Józef Radomski. In: Deans of the Faculty of Theology at John Paul II Catholic University of Lublin (1919-2009)], edited by Jan Walkusz, Tomasz Moskal, 75-94. Lublin: Wydawnictwo KUL, 2009.

MisiureK, Jerzy. "Instytut Teologii Fundamentalnej." In Katolicki Uniwersytet Lubelski Jana Pawta II. 90 lat istnienia [Institute of Fundamental Theology. In: John Paul II Catholic University of Lublin. 90 Years Anniversary], edited by Grzegorz Kramarek, Eugeniusz Ziemann, 58-60. Lublin: TN KUL, 2008.

MisiUReK, Jerzy. Teologia w Katolickim Uniwersytecie Lubelskim. Nurty-osoby-osiagnięcia [Theology at the Catholic University of Lublin. Trends-People-Achievements]. Lublin: Wydawnictwo KUL, 1999.

Moskal, Tomasz. "Piotr Antoni Kremer.” In Dziekani Wydziatu Teologii Katolickiego Uniwersytetu Lubelskiego Jana Pawta II (1919-2009) [Piotr Antoni Kremer. In: Deans of the Faculty of Theology at John Paul II Catholic University of Lublin (1919-2009)], edited by Jan Walkusz, Tomasz Moskal, 15-20. Lublin: Wydawnictwo KUL, 2009.

NAGY, Stanisław. "Sekcja Teologii Fundamentalnej.” In Księga pamiatkowa w 75-lecie Katolickiego Uniwersytetu Lubelskiego. Wktad w kulture polska w latach 1968-1993 [The Fundamental Theology Section. In: Memorial Book on the $75^{\text {th }}$ Anniversary of the Catholic University of Lublin. Contribution to Polish Culture in the Years 1968-1993], edited by Marian Rusecki, 188-197. Lublin: Wydawnictwo KUL, 1994.

RUSECKI, Marian. "Ksiądz prof. dr hab. Edward Kopeć. Życie i działalność naukowo-dydaktyczna" [Fr. Prof. Edward Kopeć. Life, Scientific and Didactic Activity.]. Roczniki Teologiczno-Kanoniczne 32(2) (1985): 7-22. 
RuSECKI, Marian. "Ksiądz prof. dr hab. Edward Kopeć.” In Dziekani Wydziału Teologii Katolickiego Uniwersytetu Lubelskiego Jana Pawta II (1919-2009) [Fr. Prof. Edward Kopeć. In: Deans of the Faculty of Theology at John Paul II Catholic University of Lublin (1919-2009)], edited by Jan Walkusz, Tomasz Moskal, 167-176. Lublin: Wydawnictwo KUL, 2009.

SeWERyniaK, Henryk. "Profesor dr hab. Stanisław Nagy SCJ—Teolog na służbie Kościoła" [Professor Stanisław Nagy SCJ. A Theologian at the Service of the Church]. Roczniki Teologiczne 62(2) (1996): 7-16.

STORY, Marek. "Ksiądz profesor Bolesław Radomski (1904-1956)" [Father Professor Bolesław Radomski (1904-1956)]. Resovia Sacra 9-10 (2002-2003): 325-330.

\section{Translated by Jan Kobytecki}

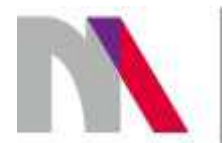

The preparation of the English version of Roczniki Teologiczne (Annals of Theology) and its publication in electronic databases was financed under contract no. 836/P-DUN/2018 from the resources of the Minister of Science and Higher Education for the popularization of science. 